\title{
Housing Demand and Affordability of Riga 21st Century Apartment Complexes
}

\author{
Santa Freimane, Riga Technical University
}

\begin{abstract}
The research focuses on the context of several issues, which are influencing housing demand and affordability of new built apartment complexes. Theoretical studies, statistical data analysis as well as housing affordability calculations were used. Research results indicate that in the current situation there are several threats, which do not allow to use full potential in order to increase sustainable housing demand and affordability of Riga 21st century apartment complexes.
\end{abstract}

Keywords - Demographics, economics, real estate, housing demand and affordability, 21st century apartments.

\section{INTRODUCTION}

Housing demand and affordability are closely related to sustainable development. According to the Sustainable Development Strategy of Riga until 2030 "the principle of sustainable development determines, that the present as well as next generations have to be provided for qualitative environment and balanced economic development, rational usage of natural, human and material resources, and saved and developed natural and cultural heritage" [1]. Residential environment plays a significant role in the context of city evolution, therefore ensuring of its qualitative development is defined as one of the most important development guidelines at all planning levels. Residential areas cover $25 \%$ of Riga territory [2], and $93.3 \%$ of citizens are living in apartment blocks [3]. These apartment blocks are mostly constructed to the standardized projects of the Soviet period and located in largescale housing estates, however, new apartment building complexes are also appearing. In the period of 2000-2016, more than 20 thousand new apartments have been built [4]. Nevertheless, knowledge about the context of demographics, economics and real estate issues regarding housing demand and affordability of new built apartments is still incomplete and needs to be improved in order to ensure progress towards sustainability.

\section{Demographics}

\section{A. Population of Latvia}

According to the statistics, in the period of 2000-2016, population of Latvia dropped by 412 thousand or $17.3 \%$, population in Riga declined by $16.5 \%$, but population in the agglomeration of Riga increased by $2.3 \%$ (Fig. 1) [5]. Although in Latvia emigration increased compared with immigration and mortality rate has gone up [6], the data shows that the counties located near Riga are able to attract citizens and are more resistant to demographic changes.

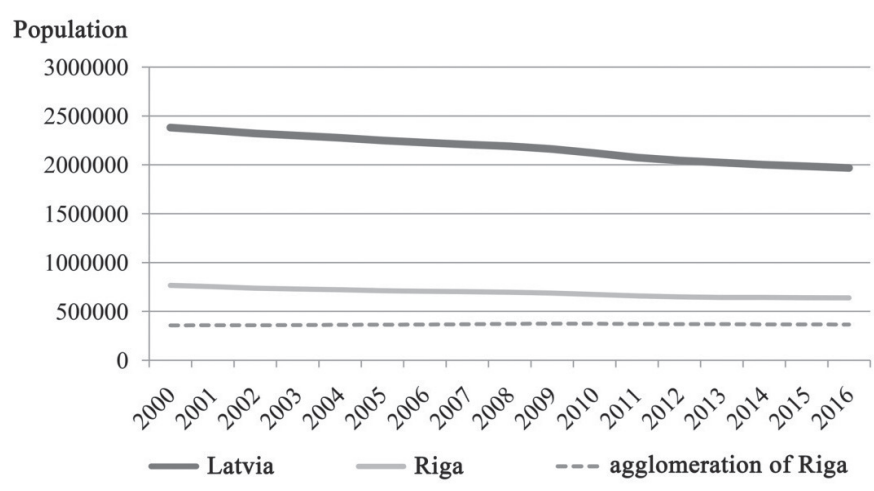

Fig. 1. Population change in the period of 2000-2016 [Picture: S. Freimane, using [5]].

In 2014, the University of Latvia published results of the research about the selection criteria of inhabitants living in agglomeration of Riga when choosing living place. Among the most mentioned criteria were such aspects as safety for oneself, family and property, peaceful living conditions and fresh air. However, $75 \%$ of all citizens of agglomeration visit Riga every day and at least $67 \%$ use daily services in Riga [7]. This situation stimulates the use of private transport, reduces population density in the city and has a negative impact on the sustainable development of the city.

\section{B. Population of Riga}

In the period of 2000-2014, population of Riga has been decreasing in almost all neighbourhoods of the city. However, the biggest reduction was stated in the central part of the city, where the number of inhabitants has dropped by $30 \%$. At the same time in Purvciems neighbourhood population has decreased only by $5 \%$ [8], which means that neighbourhoods with large scale housing estates are more resistant to population decline. In the beginning of 2016, population of Riga accounted for almost 640 thousand [5]. It is expected, that it will gradually continue to decrease and in 2030, the number of inhabitants in Riga could be in the range of 500 thousand to 580 thousand [9]. However, according to the Sustainable Development Strategy of Riga until 2030, it is planned to increase the number of inhabitants to 700 thousand, which is necessary to provide adequate social and economic stability and development of the city [1]. This could be achieved through the implementation of an appropriate policy 
ensuring the decrease in emigration, attraction of new citizens, an increase in birth rate, etc.

According to the statistics, in the period of 2005-2016, the number of households consisting of 1 person has increased by $7.7 \%$, while the number of households with 3 or more persons has decreased by $8.4 \%$ [10]. It is expected that in 2025 , more than $50 \%$ of all households will consist of 1 person or a couple without children and together with increasing energy costs, these changes will influence the demand for housing, its size and type [11]. However, for balanced change of generations, it is necessary to have enough households with two or more children [12], therefore it is necessary to provide adequate housing also for them.

In the period of 2000-2016, the population aged 15-64 has dropped by $4 \%$ and in 2016 reached 416 thousand. At the same time, the number of people aged over 62 has increased by $2 \%$ [13]. Like in many other European countries, reduced fertility and mortality promote the aging of the population [14], which increases the demographic load and adversely affects the sustainability of national economy.

\section{Floor Area per Capita}

Changes in demographics are directly related to the demand for housing. One of the calculation measures of the needed living space is floor area per capita. Since 2000, floor area per capita in Riga has gradually increased and in 2016 reached $30.0 \mathrm{~m}^{2}$ [15]. It was mainly due to new construction of housing and decline of population. However, the desired situation would be $35 \mathrm{~m}^{2}$ per capita in apartments and $53 \mathrm{~m}^{2}$ in single-family houses [16]. If in 2030 the number of inhabitants increases to 700 thousand, more than 5 million square metres of floor area will be needed to ensure adequate living conditions. If the number of inhabitants continues decreasing, less than 400 thousand square meters of floor area will be needed.

\section{ECONOMICS}

In 2008, Latvia faced economic crisis, which led to limited housing affordability. Insufficient housing affordability is a major cause of homelessness, which in turn contributes to poverty and social exclusion. Together with constant rise in prices of various housing related services such as heating, water supply, electricity, etc., an increasing number of people were unable to cover housing expenses [17]. Housing is one of the fundamental human rights to ensure quality of life. Article 25 of the Universal Declaration of Human Rights adopted by the United Nations General Assembly in 1948, states: "Everyone has the right to a standard of living adequate for the health and well-being of himself and of his family, including food, clothing, housing and medical care and necessary social services, and the right to security in the event of unemployment, sickness, disability, widowhood, old age or other lack of livelihood in circumstances beyond his control" [18]. According to the statistics, housing expenses per household member as a percentage of disposable income has decreased from $17.9 \%$ in 2011 to $14.0 \%$ in 2016 [19]. The propor- tion of households, which points to the very burdensome impact of housing related expenses, has dropped to $28.6 \%$ in 2016 [20]. The situation is improving, due to an increase of income of population, friendly bank lending policy, as well as low interest rates. However, there is a lack of affordable and appropriate housing, and the time necessary to save for a down payment is still too long [21]. Therefore, the opportunities of households to obtain homes are still limited.

\section{A. Housing Affordability}

Economics has direct impact on household income and influences housing affordability. In order to provide evaluation of housing affordability of Riga 21 st century apartment complexes, 40 research objects were selected according to the following parameters: the complex consists of at least 2 separate buildings in one compositional ensemble; at least 80 apartments are provided; the first construction phase has been completed in the period of 2000-2016.

Six out of 40 selected 21st century apartment complexes in Riga are social housing with specific renting rules. Average price per one square metre of the remaining 36 research objects is 1582 euro, which is $44 \%$ more than average price in the whole apartment sector. The price of $60 \mathrm{~m}^{2}$ large apartment in average reaches almost 95 thousand euro [22], [23] and monthly mortgage payment is in the range from 320 to 350 euro [24], [25]. In 2015, average income of households in Riga reached 1156 euro. In 2016, average gross wage in Riga was 971 euro and net wage 710 euro [26].

Housing affordability was calculated with two methods. The first one was the "Median Multiple" method, widely used in order to evaluate real estate markets and recommended by the United Nations and World Bank. Using this method, average apartment price is divided by gross annual average household income. Housing affordability rating is as follows: affordable - is rated up to 3.0 points, moderately unaffordable - in the range from 3.1 to 4.0 points, seriously unaffordable - in the range from 4.1 to 5.0 points, and severely unaffordable - from 5.1 and more points [27].

The second method was "Housing Affordability Index (HAI)", used in the research report on Baltic housing affordability index by Macro Research Department of Swedbank Large Corporates \& Institutions. The following formula of housing affordability index has been used: HAI $=[(1.5$ of average monthly net wages) / (monthly mortgage payment / $30 \%$ ) $\times 100$. If this index is higher than 100, households can afford housing. The higher the index number, the larger affordability [28].

Median Multiple indicator of 36 research objects in average reached 5.4 points (Fig. 2), which means that Riga 21st century apartment complexes are considered as severely unaffordable. At the same time housing affordability index (HAI) reached 107.6 points (Fig. 3). Although this result indicates that households can afford housing, it is much lower than average HAI in Riga, which in June 2016 reached 166.5 points [28].

Housing affordability by income quintile groups shows, that if average monthly mortgage payment of 320 euro for $60 \mathrm{~m}^{2}$ large 


\section{Median Multiple}

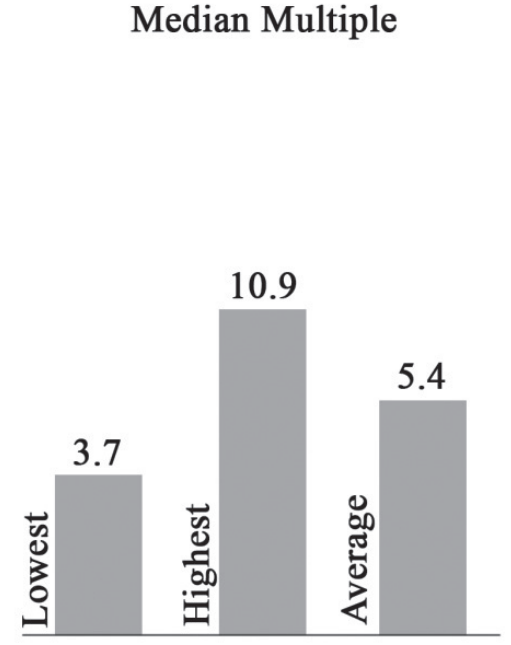

Fig. 2. The results of Median Multiple calculations [Picture: S. Freimane].

apartment does not exceed $30 \%$ of household income, only the 4 th and 5th quintile group can afford this payment. In 2016, in total these quintile groups covered $52.4 \%$ of Riga inhabitants [29]. The 1st and partially also the 2nd quintile group most likely are qualified for social apartment assignment. The 3rd quintile group cannot afford housing in new built apartment complexes and most likely is not qualified for social housing. Current situation is aggravated by the fact that each of the new build apartment complexes is in a certain price category. It means that all citizens of the complex are from the same socio-economic class. This situation is one of the threats and can lead to social segregation, because it does not provide social inclusiveness.

\section{B. Support Programs and Social Housing}

The support program ALTUM for families with children, guarantees a housing loan if a family has steady income, but does not have sufficient savings for the first down payment. If a family has one child, the amount of the guarantee is $10 \%$ and cannot exceed 10 thousand euro. If a family has two children, the amount of the guarantee is $15 \%$ and cannot exceed 15 thousand euro. But if a family has three or more children, the amount of the guarantee is $20 \%$ and cannot exceed 20 thousand euro. Since the launch of the program in 2015, ALTUM has issued more than 6 thousand guarantees with the total amount of almost 41 million euro [30]. The high figure indicates that there is the need for such support and interest from the families.

Since housing is one of the basic needs of people, some households which are in crisis situation or have insufficient material resources to provide housing, can qualify for an apartment allowance according to the Social Services and Social Assistance Law [31]. Another solution is to claim for a social apartment, if a person or a family meets one of the specified categories, such as separately living pensioners with low income, persons with the 1st or 2nd group of disability, etc. The rental agreement for social

\section{Housing affordability index} (HAI)

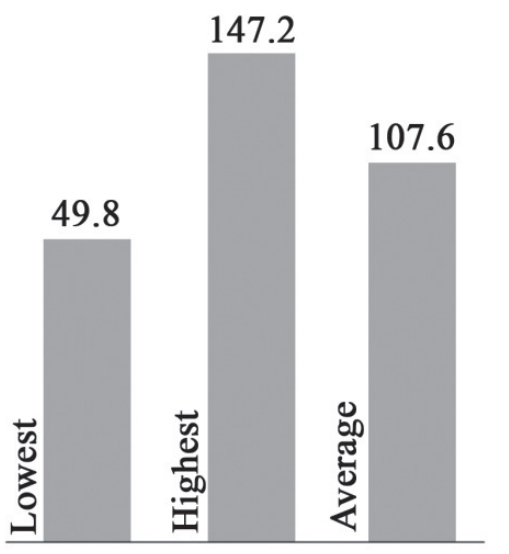

Fig. 3. The results of housing affordability index (HAI) calculations [Picture: S. Freimane].

apartment has to be concluded with the Riga City Council for six months, and if the circumstances have not changed during this period, the contract may be renewed. The rent in social housing apartments is 0.06 euro per $1 \mathrm{~m}^{2}$ and the municipality covers part of the utility payments $-25 \%$ for heating and $50 \%$ for water and sewerage. Although a number of new buildings of social housing were built, there were almost 1500 citizens of Riga registered in the social housing queue in 2015 [32], which meant that the social housing stock needed to be increased in order to resolve the existing situation.

\section{Real Estate}

\section{A. Characteristics of Housing Stock and Real Estate Market}

In 2011, almost $45.0 \%$ of all housing stock were apartment buildings, of which $19.8 \%$ were low-rise buildings, $17.9 \%$ were 5-9 storey buildings, $5.6 \%$ were $6-9$ storey buildings, and $1.4 \%$ were 10 or more storey buildings [33]. The statistics show that in 2011, distribution of citizens by the year of their residential house construction was as follows: $20 \%$ were living in houses built in the period until 1946, $72 \%$ - in houses built in the period of 1946-1990, and $8 \%$ were living in houses built in the period of 1991-2011 [33]. According to the data of the State Land Service for the year of 2014, $42 \%$ of new built apartments in Riga city centre were owned by residents, $34 \%$ - by foreigners and $23 \%$ by companies. But in other neighbourhoods $65 \%$ of new built apartments were owned by residents, $22 \%$ - by companies and $13 \%$ - by foreigners [34]. It can be concluded that the structure of apartment owners is diverse in different parts of the city and relates to the prices and policy of temporary residence permits.

Real estate market in the period of 2000-2016 was affected by several factors including the economic crisis, which contributed to changes of household income and economic activity, as well as 
changes in the field of mortgage loans and political decisions of temporary residence permits. According to statistics, the period of 2009-2010, when the economic crisis reached the lowest point, had the least number of deals in real estate market. However, the number of transactions and the price per square metre gradually has been increasing [35], indicating a recovery and stabilization of economic situation.

Although the number of 21st century apartment deals is approximately 4 times smaller than the number of standard housing deals in large scale housing estates, the total sum of transactions in new projects is equivalent and even higher [35]. Such a situation indicates exaggerated difference between new build apartments and former residential housing stock.

\section{B. Housing Demand}

The most demanded apartments in the new built apartment projects are 2 and 3 room apartments with an area of 70-75 $\mathrm{m}^{2}$ and the sum of transactions on average is 80 to 90 thousand euro. In the situation of a similar quality and area apartments, customers usually choose an apartment with more rooms, despite rooms being smaller [36]. The statistics on the offers of new built apartments and the number of transactions in the largest neighbourhoods of Riga in the 3rd quarter of 2015 show that most deals are registered in Plavnieki neighbourhood (63 deals) where there is also the largest number of offers (134 offers). At the same time, in the central part of the city there were 402 offers, however, only 84 transactions were registered [32]. The current situation shows that the number of offers in the largest neighbourhoods of Riga is approximately 4 times higher than the number of transactions, thus creating apartment surplus in real estate market. The percentage of vacant apartments in the new Riga apartment complexes in 2016 was in the range between 2 to $46 \%$ [22], [23], which leads to inefficient consumption of resources and has a negative impact on sustainability of residential environment.

Despite the availability of new offers in the city, the research on living place selection criteria of inhabitants of the Riga agglomeration, identified that the closest counties significantly compete with the capital, because they are able to offer lower prices for the same type of real estate, including renting and property acquisition. The choice is influenced also by several subjective aspects, such as air and water quality, proximity to nature, more humane scale of the living environment, which is more important for the inhabitants than the employment opportunities in the vicinity or the availability of services [7].

\section{Conclusion}

The population of Riga has declined, therefore, it is necessary to implement a policy that would allow to keep the optimal number of inhabitants in the city as well as provide rational distribution of their location in accordance with the intended density and reduce their desire to move outside Riga. The city should promote the diversity of housing supply taking into account the age structure of the population and the composition of households, as in the current situation the city faces both the aging tendency of the population and the need for a balanced process of generation change, which requires a relatively high number of large families and, consequently, adequate housing.

The fastest development of new apartment building construction was observed during the period of economic growth in 2004-2008, after which the economic crisis with a decline in construction volume followed; so far the development has not returned to the pre-crisis level. Economic crisis, together with demographic trends and competitive real estate market in agglomeration of Riga, has created a number of new challenges, including an increase in the share of empty housing in the common housing stock.

The calculations of housing affordability of Riga 21st century apartment complexes by Median Multiple method has reached 5.4 points (rated as severely unaffordable), and by housing affordability index (HAI) - 107.6 points (rated as affordable). The results are low and have to be improved in order to ensure affordable housing for all groups of population. Despite the support programs and social assistance, there is still a queue for social housing. Moreover, the situation of housing affordability by income quintile groups shows, that each complex is occupied by the same socio-economic class, thus creating a danger of segregation in residential environment.

The situation in real estate market shows that there is a lack of appropriate housing offers to match citizens' wishes, needs and opportunities. Despite the development of mortgage lending and support programs, it takes too much time to save for a down payment which is the main obstacle to the purchase of housing. Citizens' choices for housing acquisitions are limited also by the difference between the affordability of new built and standard apartments of large scale housing estates. This means that most of the households either have to choose a standard apartment or wait for an economic offer.

\section{REFERENCES}

1. Rīgas ilgtspējīgas attīstības stratēgiija līdz 2030. gadam [tiešsaite]. Rīgas domes Pilsētas attīistības departaments [skatīts 05.08.2017]. http://www. rdpad.lv/wp-content/uploads/2014/11/STRATEGIJA_WEB.pdf

2. Rìgas ilgtermiña attīstības stratēǵija līdz 2025. gadam [tiešsaite]. Rìgas domes Pilsētas attīstības departaments [skatīts 04.08.2017]. http://www. rdpad.lv/wp-content/uploads/2014/11/strategija.pdf

3. MTG03. Mājokḷa veids (\%) [tiešsaite]. Centrālās statistikas pārvaldes datubāzes [skatīts 06.08.2017]. http://data.csb.gov.lv/pxweb/lv/Sociala/ Sociala_ikgad_majapst/MTG0030.px/?rxid=cdcb978c-22b0-416aaacc-aa650 $33 \mathrm{e} 2 \mathrm{ce} 0$

4. BU06. Ekspluatācijā pienememto jauno dzīvokḷu skaits un platība statistiskajos regionos, republikas pilsētās un novados [tiešsaite]. Centrālās statistikas pārvaldes datubāzes [skatīts 02.08.2017]. http://data.csb.gov. lv/pxweb/lv/rupnbuvn/rupnbuvn isterm buvn/BU0060c.px/table/ tableViewLayout $2 /$ ?rxid= $\mathrm{d} 543 \mathrm{db} 7 \overline{\mathrm{b}}-\mathrm{f} 122-4 \mathrm{e}-1 \mathrm{f}-\mathrm{aced}-7 \mathrm{a} 7707 \mathrm{fd} 86 \mathrm{e} 7$

5. ISG032. Iedzīvotāju skaits un tā izmaiņas statistiskajos reǵionos [tiešsaite]. Centrālāss statistikas pārvaldes datubāzes [skatīts 03.08.2017]. http://data. csb.gov.lv/pxweb/lv/Sociala/Sociala ikgad iedz iedzskaits/IS0032. px/table/tableViewLayout2/?rxid=cd

6. Latvia population keeps declining; Riga population increases [online]. Centrālās statistikas pārvaldes datubāzes [cited 03.08.2017]. http://www. csb.gov.lv/en/notikumi/latvia-population-keeps-declining-riga-population-increases-45900.html

7. Felcis, R., Nikišins, J.,Zača, E. Pierīgas iedzīvotāju dzīves vietas izvēles kritēriji. Pētîjuma rezultātu atskaite [tiešsaite]. Stratēǵijas uzraudzības sistēma [skatīts 03.08.2017]. http://www.sus.lv/sites/default/files/media/ faili/lu_szf_rd_pierigas iedzivotaji_atskaite_par_petijumu.pdf

8. Iedzīvotāju skaits [tiešsaite]. apkaimes [skatīts 08.08.2017]. http://www. apkaimes.lv/stat/iedzivotaju_skaits/2014/ 
9. Eglīte, P., Ivbulis, B., Gṇedovska, I. Demogrāfiskās prognozes Rīgā un Pierīgā [tiešsaite]. Stratēǵgijas uzraudzības sistèma [skatîts 04.08.2017]. http://www.sus.lv/sites/default/files/media/faili/demografiskas prognozes riga un pieriga rd lza 2012.pdf

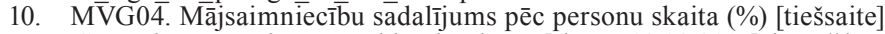
Centrālās statistikas pārvaldes datubāzes [skatīts 03.08.2017]. http://data. csb.gov.lv/pxweb/lv/Sociala/Sociala ikgad ms sastavs/MV0040.px/ table/tableViewLayout $2 /$ ?rxid $=562 \mathrm{c} 2 \overline{2} \overline{0} 5-\mathrm{ba} 5 \overline{7}-413 \overline{0}-\mathrm{b} 63 \mathrm{a}-6991 \mathrm{f} 49 \mathrm{ab} 6 \mathrm{fe}$

11. Latvijas ilgtspējīgas attīstības stratēgija līdz 2030. gadam [tiešsaite]. Vides aizsardzības un regionālās attīstības ministrija [skatīts 03.08.2017]. http://www.varam.gov.lv/lat/pol/ppd/?doc=13857

12. Pavlina, I. Valsts ǵimenes politika un tās ietekme uz domogrāfisko procesu attīstību [tiešsaite]. President [skatīts 03.08.2017]. http://www.president lv/images/modules/items/PDF/item 1125 Demografija 21gadsimts.pdf

13. SG17. Vīriešu un sieviešu vecuma struktūra statistiskajos regionos gada sākumā [tiešsaite]. Centrālās statistikas pārvaldes datubāzes [skatīts 06.08.2017]. http://data.csb.gov.lv/pxweb/lv/Sociala/Sociala_ikgad iedz iedzskaits/IS0170.px/?rxid=cdcb978c-22b0-416a-aacc-aa$650 \mathrm{~d} \overline{3}-2 \mathrm{ce} 0$

14. Meḷihovs, A. Latvijas iedz̄ivotāju skarbā nākotne [tiešsaite]. Makroekonomika [skatits 02.08.2017]. https://www.makroekonomika.lv/latvijasiedzivotaju-skarba-nakotne

15. 4.6. mājoklis [tiešsaite]. Stratēǵijas uzraudz̄̄bas sistēma [skatīts 08.08.2017]. http://sus.lv/lv/4-socialie-procesi/46-majoklis

16. Mājokḷu attīstības tematiskais plānojums (projekts) [tiešsaite]. Rìgas domes Pilsētas attīstības departaments [skatīts 04.08.2017]. http://www.rdpad.lv/ wp-content/uploads/2016/10/M\%C4\%80JOKLI/ TmP saturs MAJ.pdf

17. Pielikums 19.03.2013. vēstulei nr. Nr. 35-1-04/640 [tiešsaite]. Latvijas Republikas Labklājības ministrija [skatīts 04.08.2017]. http://www.lm.gov. lv/upload/sabiedribas_lidzdaliba/sipkk/lm_majokla_pieejamiba.pdf

18. Universal Declaration of Human Rights [online]. United Nations [cited 02.08.2017] http//www.un.org/en/universal-declaration-human-rights/

19. MTG07. Ar mājokḷa uzturēšanu saistîtie izdevumi uz vienu mājsaimniecības locekli [tiešsaite]. Centrālās statistikas pārvaldes datubāzes [skatīts 02.08.2017]. http://data.csb.gov.lv/pxweb/lv/Sociala/Sociala ikgad majapst/MTG0070.px/table/tableViewLayout2/?rxid=

20. MTĞ06. Ar mājokla uzturēšanu saistīto izdevumu ietekme uz mājsaimniecības finansiālo situāciju [tiešsaite]. Centrālās statistikas pārvaldes datubāzes [skatīts 02.08.2017]. (\%)http://data.csb.gov. lv/pxweb/lv/Sociala/Sociala ikgad majapst/MTG0060.px/table/ tableViewLayout $2 /$ ?rxid=cd

21. Meistars, J. Gaidāms hipotekāro kredītu pieaugums [tiešsaite]. SEB [skatīts 02.08.2017]. http://www.seb.lv/info/maja/gaidams-hipotekarokreditu-skaita-pieaugums

22. Jaunie mājokḷi [tiešsaite]. Latio [skatīts 02.08.2017]. http://latio.lv/lv/jaunie-majokli

23. Jaunie projekti [tiešsaite]. City24 [skatīts 02.08.2017]. http://www.city24. $\mathrm{lv} / \mathrm{lv} /$ jaunie + projekti/latvija? ord $=$ default $\& u s p=$ true $\& \mathrm{c}=\mathrm{LV} \& \mathrm{fr}=0$

24. Mājokḷa kredīta kalkulators [tiešsaite]. SEB [skatīts 04.06.2017]. http:// www.seb.lv/krediti-un-lizings/majoklim/majokla-kredita-kalkulators

25. Hipotekārā kredīta kalkulators [tiešsaite]. $D N B$ [skatīts 08.06.2017]. https://www.dnb.lv/lv/hipotekara-kredita-kalkulators

26. DSG05. Strādājošo mēneša vidējā darba samaksa Latvijas statistiskajos reǵionos (euro) [tiešsaite]. Centrālās statistikas pārvaldes datubāzes [skatīts 02.08.2017]. http://data.csb.gov.lv/pxweb/lv/Sociala/Sociala ikgad dsamaksa/DS0050 euro.px/table/tableViewLayout2/?rxid $=\overline{8} \overline{9} \mathrm{fa} 53 \mathrm{c} \overline{2}-$ 5ff7-456f-aae4-c4274cf3b2aa

27. Hartwich, O. 13th Annual Demographia International Demographia International Housing Affordability Survey: 2017 Rating Middle-Income Housing Affordability [online]. Demographia [cited 02.08.2017]. http:// www.demographia.com/dhi.pdf

28. Baltic housing affordability index [online]. AS Swedbank [cited 02.08.2017]. https://www.swedbank.lv/files/analitiskie materiali/baltijas majoklu_pieejamibas_indekss/Housing_Affordability_Index_for Baltics 2016 1Q ENG.p $\overline{d f}$

29. MVG0̄̄. Mājsaimniecību sadalījums pēc kvintiḷu grupām (\%) [tiešsaite] Centrālās statistikas pārvaldes datubāzes [skatīts 02.08.2017]. http:// data.csb.gov.lv/pxweb/lv/Sociala/Sociala ikgad ms sastavs/MV0070. $\mathrm{px} /$ ?rxid $=562 \mathrm{c} 2205-\mathrm{ba} 57-4130-\mathrm{b} 63 \mathrm{a}-\overline{699} 1 \mathrm{f} 49 \mathrm{a} \overline{\mathrm{b}} \overline{6 \mathrm{fe}}$

30. About the Housing Guarantee Programme [online]. Altum [cited 02.08.2017]. https://www.altum.lv/en/services/individuals/housing-guarantee-programme/about-the-programme/

31. Apakšgrupa "Sociālā plalīdzība" [tiešsaite]. Latvijas Pašvaldību savienība [skatīts 02.08.2017]. http://www.lps.lv/uploads/docs module/MIL majoklaPabalsts_08122015_OK_LPS.pdf

32. Sociālais dzīvokli: kam pienā $\bar{k}$ as un kā saņemt? [tiešsaite]. Kopaa [skatīts 02.08.2017]. http://kopaa.lv/pasvaldibas/socialais-dzivoklis-kam-pienakas-un-ka-sanemt.html

33. Latvijas 2011. gada tautas skaitīšanas rezultāti. Centrālās statistikas pārvalde [tiešsaite 02.08.2017]. http://www.csb.gov.lv/sites/default/files/ publikacijas/2015/Nr\%2012\%20Latvijas\%202011.gada\%20Tautas\%20 skaitisanas\%20rezultati Results\%20of\%20the\%202011\%20Populati- on $\% 20$ and $\% 20$ housing\%20census\%20in\%20Latvia\%20\%2815_00\%29 LV_EN.pdf

34. Pārskats par kadastrālās vērtēšanas modeḷa pilnveidošanu daudzfunkcionālām èkām. Valsts Zemes dienests [tiešsaite 02.08.2017]. http://kadastralavertiba.lv/wp-content/uploads/2015/02/Jaunie_projekti_PARSKATS_2014.pdf

35. Mājoklı tirgus pāarskats : Rīga un reǵgioni : 2015. gada IV ceturksnis. Latio [tiešsaite 02.08.2017]. http://latio.lv/lv/pakalpojumi/tirgus-analize/majoklu-tirgus/138/latio-majoklu-tirgus-parskats-2015-q4-final.pdf

36. Tirgus pārskats : Jaunie projekti : 3. ceturksnis. Arco Real [tiešsaite 02.08.2017]. http://www.arcoreal.lv/files/Tirgus_parskati/jaunie_projekti_novije_proekti_new_projects_2015.pdf

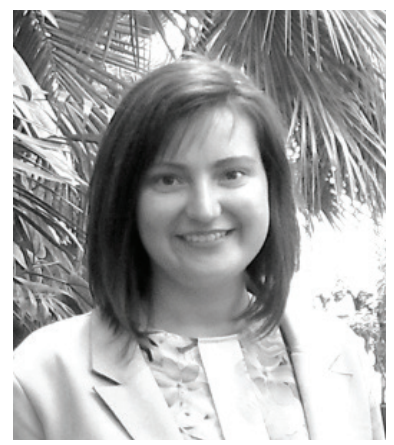

Santa Freimane received the degree of Bachelor of Architecture in 2013, Diploma of Architect in 2015, and Master of Architecture in 2017, from Riga Technical University. Since 2017, she is a PhD student with the Faculty of Architecture of Riga Technical University. She participated in the Erasmus exchange program at the Polytechnical University of Valencia in 2013.

She has been an assistant architecture with "NOMO studio" (Spain, 2016), "Architrend Architecture" (Italy, 2014), "Marta Plus" (Latvia, 2011-2013). Her main research focus is on sustainability of residential environment. The theme of her master thesis was "Sustainability of Riga 21st Century Apartment Complexes". She is currently investigating quality and identity aspects of residential environment in the context of sustainability.

She has received the Architect Janis Alksnis’ Award in 2017.

\section{Contact Data}

\section{Santa Freimane}

Faculty of Architecture,

Riga Technical University

Adress: 6 Kīpsalas St., Riga, LV-1048

Phone: +371 25878789

E-mail: arch.santafreimane@gmail.com 